\title{
Translational Utility of Liquid Biopsies in Thyroid Cancer Management
}

\author{
Ayanthi A. Wijewardene 1,2,*, Marthe Chehade ${ }^{2}$, Matti L. Gild 1,2, Roderick J. Clifton-Bligh 1,2 \\ and Martyn Bullock 1,2 (D) \\ 1 Department of Endocrinology, Royal North Shore Hospital, Sydney, NSW 2052, Australia; \\ matti.gild@sydney.edu.au (M.L.G.); roderick.cliftonbligh@sydney.edu.au (R.J.C.-B.); \\ martyn.bullock@sydney.edu.au (M.B.) \\ 2 Faculty of Medicine and Health, University of Sydney, Sydney, NSW 2052, Australia; \\ mche2952@uni.sydney.edu.au \\ * Correspondence: awij1156@uni.sydney.edu.au
}

Citation: Wijewardene, A.A.;

Chehade, M.; Gild, M.L.;

Clifton-Bligh, R.J.; Bullock, M.

Translational Utility of Liquid

Biopsies in Thyroid Cancer

Management. Cancers 2021, 13, 3443.

https://doi.org/10.3390/

cancers 13143443

Academic Editor: Iñigo Landa

Received: 11 June 2021

Accepted: 8 July 2021

Published: 9 July 2021

Publisher's Note: MDPI stays neutral with regard to jurisdictional claims in published maps and institutional affiliations.

Copyright: (C) 2021 by the authors. Licensee MDPI, Basel, Switzerland. This article is an open access article distributed under the terms and conditions of the Creative Commons Attribution (CC BY) license (https:/ / creativecommons.org/licenses/by/ $4.0 /)$.
Simple Summary: Thyroid cancer remains a challenging malignancy, and it is difficultt to scale appropriate monitoring and therapy. Monitoring of the outcomes of thyroid cancer treatment currently relies on invasive tissue biopsies or repeat imaging involving radiation exposure. Liquid biopsies are a novel technique, which assess for common mutations associated with cancer through a simple blood sample. This review will assess the utility of liquid biopsies in the diagnosis and management of thyroid cancer and outline future directions which may optimise patient outcomes.

\begin{abstract}
Liquid biopsies are a novel technique to assess for either circulating tumor cells (CTC) or circulating tumor DNA (ctDNA and microRNA (miRNA)) in peripheral blood samples of cancer patients. The diagnostic role of liquid biopsy in oncology has expanded in recent years, particularly in lung, colorectal and breast cancer. In thyroid cancer, the role of liquid biopsy in either diagnosis or prognosis is beginning to translate from the lab to the clinic. In this review, we describe the evolution of liquid biopsies in detecting CTC, ctDNA and miRNA in thyroid cancer patients, together with its limitations and future directions in clinical practice.
\end{abstract}

Keywords: liquid biopsy; circulating tumor DNA (ctDNA); cell free DNA (cfDNA); microRNA (miRNA); thyroid cancer

\section{Introduction}

Thyroid cancer is the most common endocrine malignancy, and its incidence is increasing, with approximately a quarter of million new cases diagnosed globally in 2017 [1,2]. The majority of thyroid cancer patients have an excellent outcome, with $85 \% 10$-year survival [3]. Recurrence can occur from months to years from initial diagnosis. Nearly $50 \%$ of high-risk patients will have a recurrence within 5 years [4,5]. Early identification of patients with recurrence is crucial to ensure accurate assessment and less invasive treatment options. In current practice, surveillance for thyroid cancer recurrence currently relies on serum biomarkers (including thyroglobulin in differentiated thyroid cancer (DTC) and calcitonin in medullary thyroid cancer (MTC)), radiological screening and invasive biopsies. While these modalities are the gold standard of care, they each have limitations, creating a role for new monitoring techniques in thyroid cancer management.

Liquid biopsy is the sampling and analysis of blood or other bodily fluids for informative biomarkers, such as circulating cell-free-DNA (cfDNA), microRNAs (miRNAs), proteins and metabolites. Liquid biopsies have shown to be a powerful clinical tool for several cancers, including breast, bowel, and lung cancer. In recent years, there has been an increase in the literature assessing the role of liquid biopsies in thyroid cancer. Our review 
will describe the utility of liquid biopsies in detecting common mutations in thyroid cancer patients, together with limitations and future direction in clinical practice.

\section{Modalities Used in Clinical Practice to Monitor Recurrence in Thyroid Cancer}

\subsection{Tumour Markers}

Thyroglobulin (Tg) is the most abundant protein in the thyroid gland and is generated in thyroid follicular cells. The iodination of Tg is integral in thyroid hormone production [6]. While Tg is used universally to monitor biochemical recurrence in DTC patients, it has some limitations in clinical practice. Firstly, as thyroid cancer becomes poorly differentiated, cells no longer express $\mathrm{Tg}$, making it a less reliable marker of recurrence [7]; up to $15 \%$ of patients with stimulated $\mathrm{Tg}<1 \mathrm{ug} / \mathrm{L}$ were found to have a distant metastasis, with lower $\mathrm{Tg}$ seen in tumors with an aggressive histology and $B R A F^{V 600 E}$ mutations $[8,9]$. Secondly, $30 \%$ of patients with DTC have anti-Tg antibodies, which interfere with the accuracy of the $\mathrm{Tg}$ assay [10]. Furthermore, the utility of Tg is diminished in the setting of residual normal thyroid tissue following hemithyroidectomy or subtotal thyroidectomy, used for low-risk disease [11].

Calcitonin (Ctn), is the gold-standard serum biomarker for monitoring MTC. It is a 32 amino acid peptide that results from the cleavage of procalcitonin, which are secreted from the $C$ cells of the thyroid gland. Despite new assays for Ctn having high sensitivity, falsely elevated levels can occur in conditions such as sepsis, chronic renal failure and non-thyroidal malignancies; therefore, $\mathrm{Ctn}$ needs to be appropriately interpreted in the clinical setting [12]. Ctn levels can also vary with changes in physical activity, age and weight, making it difficult to monitor treatment response over time [13].

\subsection{Imaging}

Limitations also exist in the assessment of structural recurrence with current imaging techniques. Imaging modalities used to monitor recurrence include neck ultrasounds (US), iodine scans (I-131) computed tomography (CT) and positron emission tomography (PET) scans. Neck US are limited by their capacity to differentiate benign nodules from thyroid bed recurrence [14], while repeated CT and PET scans incur ongoing radiation exposure, thus increasing the risk of secondary malignancies [15]. Therefore, while crucial in the management of thyroid cancer, the available imaging modalities can be expensive, time-consuming and confer further radiation exposure when used routinely to monitor disease progression.

\section{The Need for New Screening Tools in Thyroid Cancer: Identifying Molecular Markers}

The identification of oncogenic drivers in DTC has led to greater understanding of its pathogenesis, and some of these are now routinely used in practice. Over $70 \%$ of DTCs harbor acquired somatic mutations in $R A S(\mathrm{H}, \mathrm{K}, \mathrm{N}), B R A F, N T R K 1$, or RET rearrangements [16]. These molecular markers are used to guide prognosis, treatment choices and screening for resistance mutations. Molecular-based therapies are now in clinical practice for refractory and aggressive thyroid cancer, with tyrosine kinase inhibitors (TKI), lenvatinib and sorafenib being shown to improve progression-free survival $[17,18]$. More specific kinase inhibitors target driver mutations, e.g., selpercatinib, in RET-mutated thyroid cancers [18-20]. TKIs are limited by drug toxicities including diarrhoea, palmar-plantarerythroysesthesia and hypertension, and require close monitoring to maximise efficacy.

In current clinical practice, the identification of these important molecular markers is limited to screening tumoral tissue, which requires invasive biopsies. If tumoral samples have not been banked, then screening for these mutations may be not possible, hindering patients' access to molecular-based therapies. Furthermore, as screenings of molecular markers are limited to invasive tissue biopsies, they cannot easily be used to identify new resistance mutations or monitor treatment response. 
Liquid biopsies could comprise a novel technique to screen for these mutations via a simple peripheral blood test, opening the possibility for use in pre-operative assessment, treatment initiation and monitoring treatment response. The advantage of liquid biopsy is its ability to carry out non-invasive sampling for molecular profiling, which would normally warrant invasive biopsies with the risk of seeding, as well as capturing diseases that are not radiologically evident [21]. As it is relatively easy to perform, has a noninvasive nature, and allows for frequent sampling to track tumor evolution, liquid biopsy is an appealing option for both patients and clinicians.

\section{Genesis of Liquid Biopsy}

Liquid biopsy is the sampling and analysis of blood or other bodily fluids to assess circulating tumor cells, nucleic acids, proteins and metabolites (Figure 1). cfDNA was discovered in 1948 with the detection of free circulating DNA fragments in patients with systemic lupus erythematous [22]. cfDNA is thought to originate from the apoptosis of lymphoid and myeloid cells in normal cellular homeostasis [23,24]. Healthy older patients have higher levels of cfDNA than younger patients [25], which may reflect pathophysiological processes such as inflammation, diabetes, sepsis, and myocardial infarction [26,27]. Circulating tumor DNA (ctDNA) is, specifically, cfDNA released from apoptotic or necrotic tumor cells. Circulating tumoral cells (CTC) are metastatic tumor cells found in the circulation [28]. Both CTC and ctDNA have been used to monitor disease progression with cancer patients. ctDNA levels in cancer patients range from 0 to $>1000 \mathrm{ng} / \mathrm{mL}$ compared to 0 to $100 \mathrm{ng} / \mathrm{mL}$ in healthy controls [24]. Liquid biopsies have also played a role in the screening of patients with a high risk of cancer, with $20 \%$ of those with CTCs obtaining a diagnosis of cancer within 12 months of testing [29].

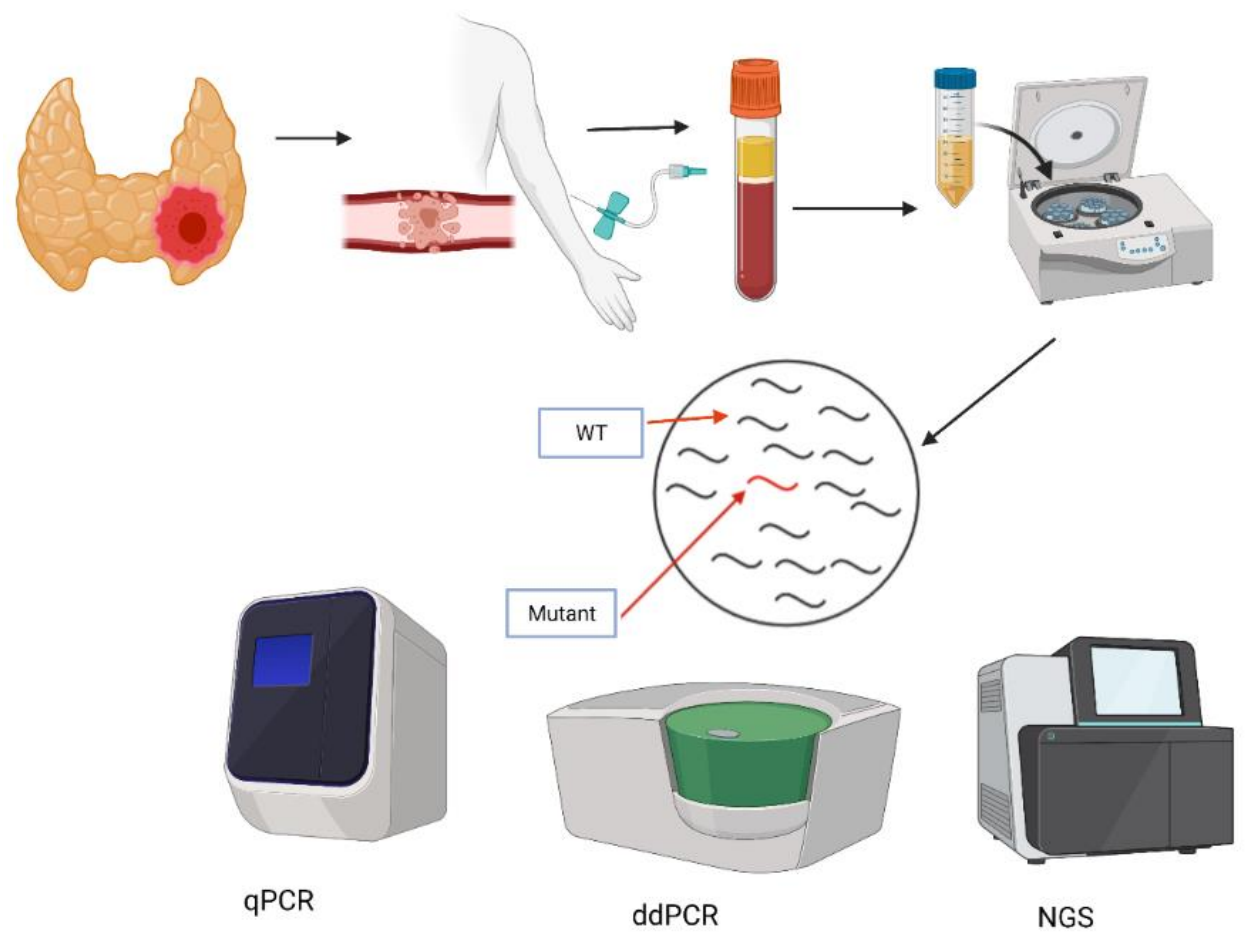

Figure 1. Detection techniques for liquid biopsies. (Created with BioRender.com, accessed on 2 March 2021.) Peripheral blood samples are collected and centrifuged to separate plasma from whole blood. DNA and RNA are extracted from plasma. Targeted mutation screening can be undertaken using Real-Time PCR (qPCR) and digital droplet PCR (ddPCR). Next-generation sequencing (NGS) allows for the screening for unknown mutations. 
Liquid biopsies are an effective tool in aiding decisions regarding oncology treatments. In non-small-cell lung cancer (NSCLC), EGFR mutation testing is used by clinicians to guide patients towards EGFR tyrosine kinase inhibitors [30,31]. ctDNA is effective in monitoring disease progression in metastatic breast cancer and colorectal cancers (CRC), with over 90\% accuracy [32-35]. Liquid biopsies can also be effective in detecting new genetic mutations in CRC that can cause treatment resistance, which, when found early, can lead to the initiation of alternative therapies [36-38].

\section{Methods of ctDNA Detection}

Techniques for the genomic profiling of cancers by liquid biopsy can be divided into two main strategies. The first is a targeted approach, whereby tumor-specific biomarker(s), identified from a prior tumor biopsy, are assayed to monitor residual disease. PCR-based assays are ideal for rapidly interrogating one or a small number of mutation hotspots. Traditional real-time PCR with hydrolysis probes is the most rapid and cheap method of ctDNA detection, although its sensitivity in detecting mutations in background wild-type (WT) DNA is limited to a mutant allele frequency (MAF) of 10-20\%. Fortunately, several different improvements to the original chemistry have led to drastic improvements in assay sensitivity. One of the most widely used of these newer techniques is competitive, allelespecific TaqMan PCR (castPCR) technology. Developed by Barbano et al., it achieves a sensitivity of $0.1 \%$ MAF by utilising a mutation-specific primer and a minor groove-binding blocker to suppress WT amplification [39]. Droplet-digital PCR (ddPCR) was developed to provide high precision and the absolute quantification of targets, and could potentially detect mutations at levels as low as $0.01 \%$. MAF. The ddPCR assay is based on water-oil emulsion droplet technology that fractionates a DNA sample into thousands of droplets, which are then PCR-amplified using allele-specific hydrolysis probes. After the PCR, each droplet either contains mutant, WT or no DNA, thus allowing for an absolute estimation of the number of mutant copies and their concentration in the reaction under the assumption of Poisson distribution. Next-generation sequencing technologies (NGS)-based amplicon panels can simultaneously genotype many hotspots; however, as it is a time-consuming and expensive approach, it may not be routinely needed for the small number of mutations that can currently inform thyroid cancer management. [40-42]. The major disadvantages of targeting screening are that it requires prior knowledge of the tumor's genetic makeup and is blind to the acquired mutations that may arise over the course of treatment. However, targeted monitoring can be extremely sensitive, as mutations can be detected at allele frequencies down to $0.01 \%$, with high specificity, in a fast and cost-effective rate manner.

The second strategy used to analyze ctDNA involves high-throughput NGS-based assays to perform untargeted genome-wide screening. Untargeted screening requires no prior knowledge of the cancer's genomic makeup and identifies novel changes occurring over time. However, it is more costly and time-consuming and requires a relatively large amount of input ctDNA, which is often unattainable. Despite its high sensitivity and specificity, the random PCR error rate using NGS is still $0.1-1 \%$ depending on the platform used, which is unacceptably high for the confident identification of rare mutations in ctDNA. Traditional deep sequencing (coverage $>10,000 \times$ ) can drill down to $0.2 \%$ but the requirement for such a high coverage drastically escalates sequencing costs. Duplex sequencing is one of the most accurate methods for detecting low-abundance mutations, achieving 1000-fold fewer errors than standard sequencing, but it is also significantly more costly. By requiring mutations to be present in replicate reads from both strands of each DNA duplex, errors introduced by sample preparation and sequencing can be overcome [43] Another approach, Bias-Corrected Targeted NGS, drastically improves the signal-to-noise ratio by using tags that are connected to each captured DNA fragment, so that every sequencing read is anchored to its clonal family and pull-down probe of origin, facilitating the identification of low-frequency mutant alleles and quantification of subtle changes in gene copy numbers [44]. 
Mutation-enrichment methods can also be employed to elevate mutation concentrations to levels at which accurate and precise downstream analysis becomes feasible, with less sensitive detection methods. Nuclease-assisted Minor Allele Enrichment with Probe-Overlap (NaME-PrO) [45] and CRISPR-mediated, ultrasensitive detection of target DNA-PCR (CUT-PCR) [46] can be employed to selectively digest WT DNA, and thus alter rare mutations to more readily detectable levels. Both techniques have been demonstrated to enrich point mutations, and $\mathrm{NaME}-\mathrm{PrO}$ has also proven to be effective for microsatellite instability (MSI) targets [47], while an adaptation called Methylation Specific NucleaseAssisted Minor-Allele Enrichment (MS-NaME) can target the methylated or unmethylated minority-epigenetic-allele [48].

\section{Liquid Biopsy in Thyroid Cancer}

As in the other cancers described, the emerging role of liquid biopsies in thyroid cancer can provide vital information on somatic and epigenetic mutations, which can guide treatment decision. Early research focused on the gross quantification of cfDNA and detection of CTC. Thyroid cancer patients were found to have longer DNA strands and more cfDNA in their circulation than healthy controls when quantified by qPCR [49].

More recently, liquid biopsy techniques have evolved, and can detect specific mutations, primarily $B R A F^{V 600 E}$ and $R E T^{M 918 T}$ in plasma DNA samples. $B R A F^{V 600 E}$, an oncogenic mutation, is never present in benign disease, yet it is detected in about twothirds of all differentiated thyroid cancers [50]. Assessment of BRAFV600E status is now standard in the risk stratification of PTC and an essential determinant of treatment options for anaplastic thyroid cancer (ATC) [51-55]. RET rearrangements are the second most common somatic alteration seen in PTC, and occur in up to $40 \%$ of PTC [56]. RET rearrangements are not seen in normal thyroid epithelial cells [57]. RET rearrangement causes the constitutive activation of tyrosine kinase activity through the MAPK pathway. Like $B R A F^{V 600 E}, R E T$ fusions are associated with classic PTC; however, unlike $B R A F^{V 600 E}, R E T$ fusions are not associated with poor prognosis in PTC patients [57]. In contrast to PTC, MTC is associated with single-acid mutations and deletions. MTC occurs sporadically in over $75 \%$ of cases, with over $50 \%$ harbouring the $R E T^{M 918 T}$ point mutation. The remaining $25 \%$ MTC cases are due to a germline RET mutation associated with Multiple Endocrine Neoplasia type 2 [58]. In MTC, knowledge of mutational status is vital for treatment decisions, due to a strong phenotype/genotype correlation.

Liquid biopsies have allowed for these molecular markers to be detected by a simple blood test, opening its role as modality to be used in aiding diagnosis and prognosis, and monitoring treatment response (Table 1). 
Table 1. ctDNA markers for the diagnosis and surveillance of thyroid cancer.

\begin{tabular}{|c|c|c|c|c|c|}
\hline Study & Subjects & Mutation & Detection Technique & $\begin{array}{l}\text { Concordance of } \\
\text { ctDNA to Tissue }\end{array}$ & Comments \\
\hline \multicolumn{6}{|l|}{ Mutational Screening } \\
\hline Condello et al. (2015) [59] & 22 PTC ( $n=4$ distant metastasis) & $B R A F^{V 600 E}$ & $\begin{array}{l}\text { ddPCR } \\
\text { qPCR }\end{array}$ & $0 \%$ & \\
\hline Kwak et al. (2013) [60] & 94 PTC ( $n=43 ;$ stage $3 / 4$ disease) & $B R A F^{V 600 E}$ & qPCR & $0 \%$ & \\
\hline Jensen et al. (2020) [61] & 57 PTC & $B R A F^{V 600 E}$ & $\begin{array}{c}\text { ddPCR } \\
\text { COLD PCR }\end{array}$ & $42.1 \%$ & $\begin{array}{l}\text { Tumor size, gross ETE, pulmonary } \\
\text { micro-metastases associated with increases }\end{array}$ \\
\hline Kim et al. (2015) [62] & 49 PTC ( $n=3$ lung metastasis) & $B R A F^{V 600 E}$ & PCR & $6.1 \%$ & $\begin{array}{c}100 \% \text { concordance in } 3 \text { patients with lateral LN } \\
\text { and lung metastasis }\end{array}$ \\
\hline Almubarak et al. (2020) [63] & 28 DTC & $B R A F^{V 600 E}$ & ddPCR & $100 \%$ & \\
\hline Cote et al. (2017) [64] & $50 \mathrm{MTC}$ & $R E T^{M 918 T}$ & ddPCR & $32 \%$ & $\begin{array}{l}\text { Presence of RETm918T associated with worse } \\
\text { clinical outcomes and calcitonin doubling in time }\end{array}$ \\
\hline Allin et al. (2018) [65] & $\begin{array}{c}42 \text { advanced thyroid caner (15 PTC, } \\
14 \text { MTC, } 10 \text { FTC, } 2 \text { PDTC \& } \\
1 \text { ATC) }\end{array}$ & $\begin{array}{l}\text { BRAF } \\
\text { NRAS } \\
\text { RET }\end{array}$ & ddPCR & $67 \%$ (combined) & \\
\hline Qin et al. (2021) [67] & 87 ATC & $\begin{array}{l}\text { BRAF V600E } \\
\quad \text { TERTp }\end{array}$ & NGS & $\begin{array}{c}92.9 \%\left(B R A F^{V 600 E}\right. \\
\text { naïve) } \\
83.7 \%\left(B R A F^{V 600 E}\right. \\
\text { previous treatment } \\
5.8 \%(T E R T p)\end{array}$ & $\begin{array}{l}\text { Higher concordance in treatment naive than } \\
\text { previously treated }\end{array}$ \\
\hline Suh et al. (2021) [68] & 62 early stage DTC & $\begin{array}{l}\text { BRAFV600E } \\
\text { TERTp } \\
\text { NRAS } \\
\text { KRAS }\end{array}$ & qPCR & $0 \%$ (combined) & \\
\hline
\end{tabular}


Table 1. Cont.

\begin{tabular}{|c|c|c|c|c|c|}
\hline Study & Subjects & Mutation & Detection Technique & $\begin{array}{l}\text { Concordance of } \\
\text { ctDNA to Tissue }\end{array}$ & Comments \\
\hline \multicolumn{6}{|l|}{ Treatment } \\
\hline Pupilli et al. (2013) [69] & $\begin{array}{c}N=19 \text { patients tested pre and post } \\
\text { operatively }\end{array}$ & $B R A F^{V 600 E}$ & qPCR & NA & $\begin{array}{l}\text { ctDNA levels reduced } 3-6 \text { months } \\
\text { post-operatively }(p<0.001)\end{array}$ \\
\hline Konda et al. (2017) [70] & 7 DTC & $B R A F^{V 600 E}$ & ddPCR & NA & $\begin{array}{l}\text { Undetectable ctDNA following treatment with } \\
\text { dabrafenib }\end{array}$ \\
\hline Besse et al. (2018) [71] & $\begin{array}{l}29 \text { MTC } \\
9 \text { PTC }\end{array}$ & $R E T$ & NGS & $76 \%$ & $\begin{array}{l}\text { Selpercatinib resulted in } 50 \% \text { reduction in variant } \\
\text { allele frequency (VAF) in } 79 \% \text { of sampled patients } \\
\text { following treatment }\end{array}$ \\
\hline Busaidy et al. (2017) [72] & 16 MTC & $R E T^{M 918 T}$ & ddPCR & $61.5 \%$ & $\begin{array}{l}13 \text { patients treated with TKI- } 8 \text { with progressive } \\
\text { disease developed new RET V804M mutations }\end{array}$ \\
\hline \multicolumn{6}{|l|}{ Suspicious Nodules } \\
\hline Salvianti et al. (2017) [49] & $\begin{array}{l}\text { Bethesda } 4 \text { and } 5(n=28) \\
\text { Bethesda } 2 \text { and } 3(n=69) \\
\text { Healthy control }\end{array}$ & cfDNA & qPCR & NA & $\begin{array}{c}\text { AUC of } 0.765(p<0.001), 0.982(p<0.001) \text { and } \\
0.796(p<0.001) \text { for cfDNA quantity by } 67 \mathrm{bp} \\
\text { amplicon, cfDNA quantity by } 180 \text { bp amplicon } \\
\text { and integrity index, respectively }\end{array}$ \\
\hline Lupo et al. (2018) [73] & $\begin{array}{c}56 \text { nodular diseases } \\
\text { (13 malignant, } 43 \text { benign })\end{array}$ & 96 gene Panel & NGS & NA & $\begin{array}{l}\text { 1/13 malignant and } 2 / 43 \text { benign had positive } \\
\text { ctDNA }\end{array}$ \\
\hline Pupilli et al. (2013) [69] & $\begin{array}{c}103 \text { nodular gotire } \\
(n=19 \text { screened with bloods post } \\
\text { operatively) }\end{array}$ & $B R A F^{V 600 E}$ & qPCR & NA & $\mathrm{AUC}=0.797, p<0.001$ \\
\hline Cao et al. (2020) [74] & $\begin{array}{l}10 \text { benign nodules } \\
10 \text { malignant nodules }\end{array}$ & $\begin{array}{l}50 \text { amplicon } \\
\text { library panel }\end{array}$ & NGS & $0 \%$ & \\
\hline
\end{tabular}




\section{Clinical Applications}

\subsection{Mutational Screening}

The utility of ctDNA to detect $B R A F^{V 600 E}$ mutations has had mixed results, with some studies showing no ctDNA detectioin patients with known $B R A F^{V 600 E}$ mutations in both localised and metastatic disease. In a cohort of 22 patients, including four with distant metastasis, who had confirmed BRAF $F^{V 00 E}$ mutations on tissue samples, no ctDNA was detected using ddPCR or qPCR [59]. In 94 patients, with a mean tumor size of $9.9 \mathrm{~mm}$, the $B R A F^{V 600 E}$ mutation could not be detected using $\mathrm{qPCR}$, including four patients with stage 4 disease [60]. More positive studies showed that $B R A F^{V 600 E} c t D N A$ was identified in $42.1 \%$ (24/57) patients with PTC and known tumoral mutation using ddPCR, and more often in those with higher risk disease (12/16) [61]. In a study using DNA-mediated clamping PCR, of 49 patients with known BRAF ${ }^{V 600 E}$ tumoral mutations, only $6.1 \%$ of patients had a concordant ctDNA, all of which had lung metastasis [62]. In more recent years $B R A F^{V 600 E} c t D N A$ was reported to have a $100 \%$ concordance in 28 DTC patients with known $B R A F^{V 600 E}$ mutation using ddPCR. The variant allele frequency (VAF) of $B R A F^{V 600 E}$ in cfDNA ranged from 0 to $2.07 \%$ in patients with persistent disease, while it was only $0-0.04 \%$ in patients with no evidence of disease. ctDNA levels, when compared to Tg levels, had higher sensitivity and specificity in detecting disease status and tumor burden [63].

The concordance between mutant RET ctDNA compared to tissue biopsy has had varied between results. In a cohort of 50 MTC patients who tested positive for $R E T^{M 918 T}$ following tissue biopsy, the mutation was detected (via ddPCR) in only $32 \%$ [64]. Patients with higher levels of mutant $R E T^{M 918 T}$ in ctDNA, had worse overall survival [64]. In two smaller studies, concordance between ctDNA and tissue was higher, at $61.5-76 \%$ [71,72].

In a cohort of 42 advanced thyroid cancer patients with known tumoral mutations, there was a $67 \%$ concordance with ctDNA using ddPCR. Concordance rates varied depending on histology, with highest rates in poorly differentiated and anaplastic thyroid cancer $(100 \%)$. Concordance was $79 \%$ for MTC, 60\% in follicular thyroid cancer and 53\% in PTC.

NGS panels have increasingly been used to detect somatic mutations in thyroid cancer. In 23 patients with ATC, concordance between tissue and ctDNA was the highest in $B R A F^{V 600 E}(7 / 10)$ and NRAS (3/4), and in those patients with persistent disease at time of NGS [66]. More recently, the same group compared mutations between cfDNA and tissue in a group of 87 ATC patients on the Guardian 360-73 gene platform [67]. At least one mutation was detected in $92 \%$ of patients, with a concordance of $92.9 \%(26 / 28)$ seen for $B R A F^{V 600 E}$, with a PPV of $100 \%$. Patients with cfDNA-detected PIK3CA mutation had a worse overall survival than PIK3CA WT ATC patients. Notably TERTp mutations, present in $65-72.7 \%$ of ATC patients $[75,76]$, are difficult to detect in ctDNA, with these mutations found in only $5.8 \%$ of 87 ATC patients on NGS testing of cfDNA [67].

\subsection{Monitoring Treatment Response}

The management of thyroid cancer has previously been limited to local therapies, including surgery and radiation therapy. Recently, the development of molecular-based therapies has provided the potential for disease control in patients with advanced and radioactive iodine refractory disease [18,77]. Lenvatinib and sorafenib are multitargeted TKI, and have been shown to improve progression-free survival $[17,18]$. More specific kinase inhibitors target driver mutations, e.g., selpercatinib, in RET-mutated thyroid cancers [18-20]. TKIs are associated with significant drug toxicities, including diarrhoea, palmar-plantar-erythroysesthesia and hypertension; therefore, it is vital to determine the optimal time at which to commence therapy, while also closely monitoring the response, to maximise efficacy [78]. ctDNA provides the potential to monitor mutational load while screening for new mutations, which may lead to treatment resistance.

Measuring $B R A F^{V 600 E}$ in ctDNA has been found to be effective in monitoring treatment response. In a study of 19 patients, the MAF of $B R A F^{V 600 E}$ was significantly reduced 3-6 months following surgery [69]. Similarly, in a cohort of 20 patients with known tumoral $B R A F^{V 600 E}$, seven $(35 \%)$ had detectable $B R A F^{V 600 E}$ on ctDNA at baseline; after three 
cycles of dabrafenib and trametinib, all seven had undetectable $B R A F^{V 600 E}$, and increased $B R A F^{V 600 E}$ ctDNA was then seen in those whose disease subsequently progressed [70].

A study of ctDNA from 34 MTC patients on selpercatinib, which included 13 mutations and 21 fusions, found a 50\% reduction in VAF in $79 \%$ of sampled patients following treatment, again showing ctDNA's potential in monitoring treatment response [71]. More recently, eight patients with progressive disease on non-specific RET inhibitors, vandetanib or cabozantinib, were found to develop the gatekeeper mutation $R E T^{V 804 M}$, which is associated with treatment resistance, using to liquid biopsy [72]. The early identification of resistance mutations is a vital role for the future of ctDNA.

\subsection{Diagnostic Applications: Assessment of Suspicious Nodules}

In large cohort of 103 patients with nodular goitre, ctDNA BRAF V600E mutations were highest in patients with Bethesda 4 (suspicious of malignancy) and 5 (malignant) nodules [69].

qPCR was used to compare cfDNA tumour strands (67 vs. 180 amplicons) between Bethesda 4 and 5 nodules $(n=28)$ to Bethesda 2 and $3(n=69)$ and healthy control $(n=49)$, and found longer tumor stands, associated with higher risk nodules [49].

In contrast, a study of 66 patients with thyroid nodules and no previous history of thyroid cancer found no statistical difference between cfDNA levels in benign and malignant nodules using a 96-mutation NGS panel [73]. In a small study comparing 10 patients with benign nodules to 10 patients with malignant nodules, $B R A F^{V 600 E}$ was only detected in patients with malignant nodules on tissues, and not in ctDNA [74].

In 62 patients with early-stage thyroid cancer, BRAF ${ }^{V 600 E}, R E T, N R A S$ and TERTp mutations were not detected in ctDNA using qPCR; however, one healthy control (1.9\%) harboured a KRAS mutation in their plasma sample [68].

\section{Liquid Biopsies of Epigenetic Markers}

Liquid biopsies have evolved in recent years to detect epigenetic markers. Epigenetic makers broadly encompass changes in gene expression that do not result in permanent changes to DNA and include DNA methylation and miRNA. Epigenetic makers often occur early in tumorigenesis and are poised to be future therapeutic targets.

\subsection{Circulating miRNA}

miRNA are short, non-protein-coding RNA transcripts that act to negatively regulate gene expression through messenger RNA (mRNA) translational inhibition or transcript decay [79]. Long, non-coding RNA (lncRNA) transcripts which span more than 200 nucleotides and regulate gene expression by manipulating nuclear architecture, modulating mRNA stability, and regulating mRNA translation and post-translational modification [80]. Aberrant expression of these non-coding RNAs is associated with tumor development in a tissue-specific pattern, which may be exploited to develop diagnostic and prognostic tools. miRNAs have also been proposed as prognostic biomarkers in PTC, with miR146b-5p [81-83], miR-21 [84,85], miR-1996b-5p [82], miR-221 [83,86] and miR-222 [83,86] overexpression being associated with lymph node and distant metastases. As the lifetime prevalence of lymph node and distant recurrence in PTC patients approximates 20\% [87], the miRNA and lncRNA profiling of PTC tumors could be used to tailor patient surveillance of recurrence risk.

The stability of the miRNA shed from tumor cells in bodily fluids and circulating protein complexes makes them attractive as potential non-invasive disease biomarkers [88]. There have been several studies investigating the clinical utility of circulating miRNAs in thyroid cancer (Table 2), in which miR-451a [89,90], miR-146a-5p [89,91,92] and miR-222 $[93,94]$ were reproducibly able to differentiate between patients with PTC and benign nodules. Only miR-222 discriminated between PTC and benign nodules on pre-operative samples (AUC 0.906), with a minimal improvement in diagnostic accuracy using a combined miRNA panel approach (AUC 0.917) [93]. 
Table 2. Circulating miRNA biomarkers for the diagnosis and surveillance of thyroid cancer.

\begin{tabular}{|c|c|c|c|c|c|c|c|c|}
\hline Study & Subjects & Sample & Sampling Time & Normalisation & Analysis Method & \multicolumn{2}{|c|}{ Differentially Expressed miRNA } & AUC \\
\hline Yoruker et al., 2016 [95] & $\begin{array}{l}31 \mathrm{PTC} \\
31 \mathrm{MNG} \\
24 \mathrm{HC}\end{array}$ & Serum & $\begin{array}{l}\text { Pre-operative } 5 \\
\text { weeks post-op }\end{array}$ & $m i R-16 \mathrm{EC}$ & RT-qPCR & $\begin{array}{l}\downarrow \text { in PTC and MNG relative to HC } \\
\downarrow \text { in PTC postop relative to preop }\end{array}$ & $\begin{array}{l}m i R-21 \\
m i R-31 \\
m i R-151-5 p \\
m i R-221 \\
m i R-222\end{array}$ & \\
\hline Zou et al., 2020 [96] & $\begin{array}{c}100 \mathrm{PTC} \\
30 \mathrm{MNG} \\
96 \mathrm{HC}\end{array}$ & $\begin{array}{c}\text { Serum } \\
\text { exosomes }\end{array}$ & Pre-operative & $\begin{array}{l}\text { C. elegans miR-39 } \\
\text { spike-in control }\end{array}$ & $\begin{array}{c}20 \text { PTC, } 20 \text { MNG, } \\
10 \text { HC Screening } \\
\text { cohort microarray } \\
\text { Training, testing } \\
\text { and Validation } \\
\text { cohort RT-qPCR }\end{array}$ & $\uparrow$ in PTC relative to HC & $\begin{array}{c}\text { miR-25-3p } \\
\text { miR-296-5p } \\
\text { miR-92a-3p } \\
\text { Combined panel }\end{array}$ & $\begin{array}{l}0.623 \\
0.621 \\
0.702 \\
0.775\end{array}$ \\
\hline Zhang et al., 2019 [89] & $\begin{array}{l}100 \mathrm{PTC} \\
15 \mathrm{MTC} \\
91 \mathrm{BN} \\
89 \mathrm{HC}\end{array}$ & Serum & Pre-operative & let-7d/g/I EC & $\begin{array}{l}\text { TLDA screening } \\
\text { RT-qPCR } \\
\text { validation }\end{array}$ & $\begin{array}{c}\uparrow \text { in PTC and BN relative to HC } \\
\downarrow \text { in PTC and BN relative to HC } \\
\uparrow \text { in MTC relative to BN * and HC }\end{array}$ & $\begin{array}{c}\text { miR-222-3p } \\
\text { miR-17-5p } \\
\text { miR-451a } \\
\text { miR-146a-5p } \\
\text { miR-132-3p } \\
\text { miR-183-3p } \\
\text { miR-222-3p } \\
\text { miR-17-5p } \\
\text { combined panel }\end{array}$ & $\begin{array}{l}0.858 \text { * } \\
0.840 \text { * } \\
0.907^{*}\end{array}$ \\
\hline Graham et al., 2015 [91] & $\begin{array}{l}18 \mathrm{PTC} \\
13 \mathrm{BN}\end{array}$ & Serum & Pre-operative & $\begin{array}{l}\text { MS2 } \\
\text { bacteriophage } \\
\text { RNA spike-in } \\
\text { control }\end{array}$ & RT-qPCR & $\begin{array}{l}\downarrow \text { in PTC relative to BN } \\
\uparrow \text { in PTC relative to BN }\end{array}$ & $\begin{array}{c}\text { miR-146a-5p } \\
\text { miR-199b-3p } \\
\text { miR-10a-5p } \\
\text { let-7b-5p }\end{array}$ & \\
\hline $\begin{array}{l}\text { Rosignolo et al., } 2017 \\
\text { [92] }\end{array}$ & $\begin{array}{l}44 \mathrm{PTC} \\
19 \mathrm{BN} \\
20 \mathrm{HC}\end{array}$ & Serum & $\begin{array}{l}\text { Pre-operative } 30 \\
\text { days post-op }\end{array}$ & $\begin{array}{l}\text { C. elegans } m i R-39 \\
\text { spike-in control }\end{array}$ & $\begin{array}{l}11 \text { PTC screening } \\
\text { cohort TLDA } \\
\text { RT-qPCR } \\
\text { validation }\end{array}$ & $\downarrow$ in PTC postop relative to preop & $\begin{array}{l}\text { miR-146a-5p } \\
\text { miR-221-3p } \\
\text { miR-222-3p }\end{array}$ & $\begin{array}{l}0.653 \text { * } \\
0.730 \text { * } \\
0.587^{*}\end{array}$ \\
\hline
\end{tabular}


Table 2. Cont.

\begin{tabular}{|c|c|c|c|c|c|c|c|c|}
\hline Study & Subjects & Sample & Sampling Time & Normalisation & Analysis Method & Differentially Expresse & iRNA & AUC \\
\hline Yu et al., 2012 [93] & $\begin{array}{c}106 \mathrm{PTC} \\
95 \mathrm{BN} \\
44 \mathrm{HC}\end{array}$ & Serum & $\begin{array}{l}\text { Pre-operative 5-15 } \\
\text { days post-op }\end{array}$ & $m i R-16 \mathrm{EC}$ & $\begin{array}{c}\text { Solexa sequencing } \\
\text { screening } \\
\text { RT-qPCR } \\
\text { validation }\end{array}$ & $\begin{array}{l}\uparrow \text { in PTC relative to BN and HC } \\
\downarrow \text { in PTC postop relative to preop }\end{array}$ & $\begin{array}{c}\text { let-7e } \\
\text { miR-151-5p } \\
\text { miR-222 } \\
\text { combined panel }\end{array}$ & $\begin{array}{l}0.782 \text { * } \\
0.780 \text { * } \\
0.906^{*} \\
0.917 \text { * }\end{array}$ \\
\hline Ferracin et al., 2015 [97] & $\begin{array}{l}27 \mathrm{TC} \\
60 \mathrm{HC}\end{array}$ & Plasma & Pre-operative & $\begin{array}{l}\text { C. elegans miR-39 } \\
\text { spike-in control }\end{array}$ & ddPCR & $\uparrow$ in $\mathrm{TC}$ relative to $\mathrm{HC}$ & $m i R-181 a-5 p$ & 0.870 \\
\hline Li et al., 2015 [90] & $\begin{array}{l}56 \mathrm{PTC} \\
95 \mathrm{BN} \\
10 \mathrm{HC}\end{array}$ & Plasma & $\begin{array}{l}\text { Pre-operative } 4-7 \\
\text { days post-op }\end{array}$ & U6 RNA EC & $\begin{array}{l}\text { microarray } \\
\text { screening } \\
\text { RT-qPCR } \\
\text { validation }\end{array}$ & $\begin{array}{c}\uparrow \text { in PTC relative to BN and HC } \\
\downarrow \text { in PTC postop relative to preop }\end{array}$ & $\begin{array}{c}m i R-25-3 p^{\alpha} \\
m i R-451 a^{\alpha} \\
m i R-140-3 p \\
\text { let-7i }\end{array}$ & $\begin{array}{l}0.835^{*} \\
0.857^{*}\end{array}$ \\
\hline Lee et al., 2015 [98] & $\begin{array}{l}70 \mathrm{PTC} \\
19 \mathrm{BN}\end{array}$ & Plasma & Pre-operative & $\begin{array}{l}\text { C. elegans miR-39 } \\
\text { spike-in control }\end{array}$ & RT-qPCR & $\uparrow$ in PTC relative to $\mathrm{BN}$ & $\begin{array}{l}m i R-146 b \\
m i R-155\end{array}$ & $\begin{array}{l}0.649^{*} \\
0.695^{*}\end{array}$ \\
\hline $\begin{array}{c}\text { Kondrotiene et al., } 2020 \\
\text { [94] }\end{array}$ & $\begin{array}{c}49 \mathrm{PTC} \\
23 \mathrm{MNG} \\
57 \mathrm{HC}\end{array}$ & Plasma & $\begin{array}{l}\text { Pre-operative } 1 \\
\text { month post-op }\end{array}$ & $\begin{array}{c}\text { C. elegans } \\
\text { miR-39-3p spike-in } \\
\text { control }\end{array}$ & RT-qPCR & $\begin{array}{c}\uparrow \text { in PTC relative to HC } \\
\downarrow \text { in PTC postop relative to preop }\end{array}$ & $\begin{array}{c}\text { miR-221 } \\
\text { miR-222 } \\
m i R-146 b \\
m i R-21 \\
m i R-181 b \\
m i R-21 \\
m i R-221 \\
m i R-146 b \\
m i R-181 b\end{array}$ & 0.711 * \\
\hline
\end{tabular}

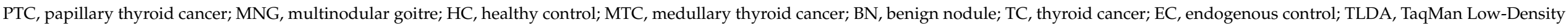

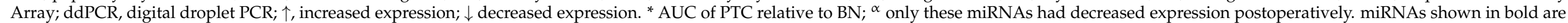
differentially expressed in multiple studies. 
At present, significant obstacles have limited the translation of circulating miRNAs to clinically useful diagnostic tools. Among these, the absence of standardised protocols for sample processing and multiple approaches to the normalisation of expression data have resulted in heterogenous pre-clinical datasets, which are not easily comparable.

\subsection{Methylation}

RAS association domain family protein 1 (RASSF1) and sodium transporter coding gene (SLC5A5) are silenced by promoter methylation in thyroid cancer, with increased methylation levels associated with aggressive disease [99]. In a seminal study, 6689 peripheral blood samples were screened for $>1000,000$ methylation regions, detecting more than 50 types of malignancy, including thyroid cancer, with a specificity of $99.3 \%$ [100]. Methylation signatures were increased in patients with histologically confirmed malignant nodules compared to those with benign pathology [101-103].

\subsection{Future Directions}

Liquid biopsy has the potential to become increasingly used for the diagnosis and surveillance of thyroid cancer. As a simple peripheral blood test with the capacity to detect important molecular markers, it has the scope to be used in many clinical applications including aiding in surgical planning, screening for mutations to aid treatment decisions and resistance mechanisms (Figure 2). In the era of targeted therapy, liquid biopsies provide a simple tool and reduce the need for invasive biopsies to gauge eligibility and monitor treatment response. Furthermore, with the increasing incidence of thyroid cancer, cost-effective and low-risk monitoring, and diagnostics with high sensitivity and specificity, will reduce the burden of long-term follow-up. Limitations to its widespread applicability include the low levels of ctDNA in patients with thyroid cancer, and currently limited evidence base, with small sample sizes and variable methods used to detect and report ctDNA. Improved TERTp detection in liquid biopsies, which is notoriously difficult to amplify due to their high GC content, would aid in the prognostication and treatment planning for patients with thyroid cancer. Further studies are also required on the role of other epigenetic markers, including histone modification and copy number alteration, which have been associated with onset and progression in other malignancies and need to be determined for thyroid cancer.

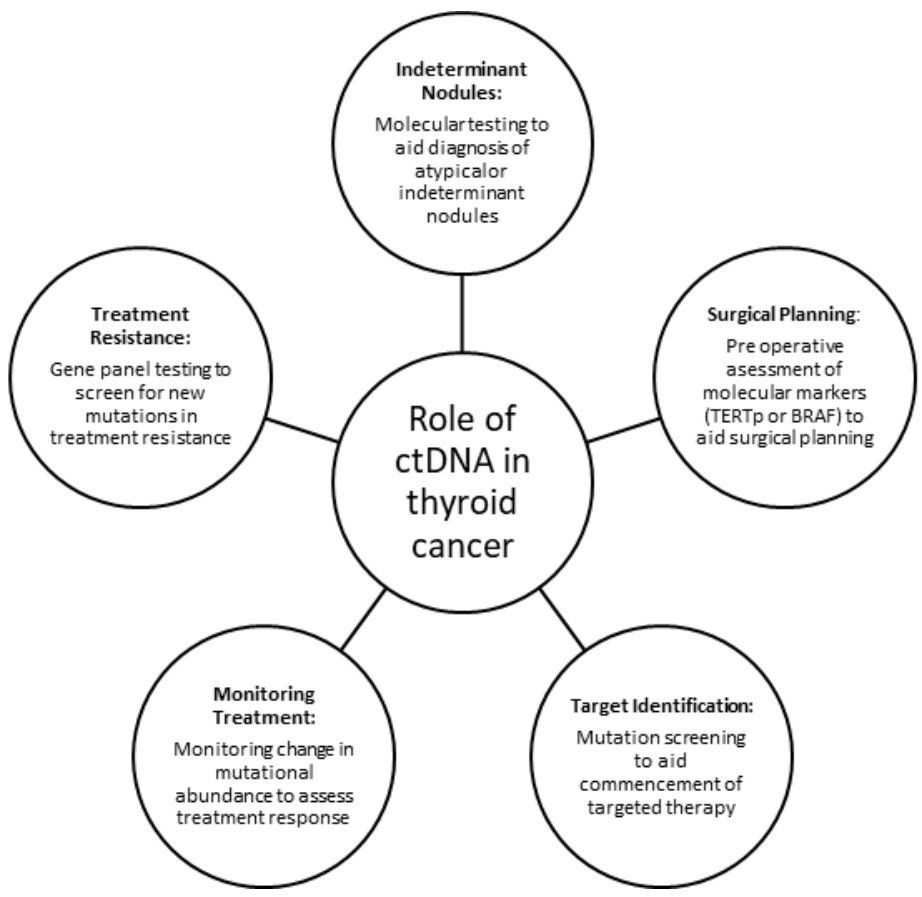

Figure 2. Potential role of liquid biopsy in thyroid cancer. 


\section{Conclusions}

Liquid biopsy is an emerging technique to screen for molecular biomarkers in peripheral blood samples of cancer patients. Advances in amplification techniques allow for the detection of only a few copies of mutant alleles; however, the inconsistent results and variable methodology between studies have limited its clinical application to date. The potential of liquid biopsies to improve screenings for patients with thyroid cancer warrants ongoing research to improve the technique and allow for its translation from bench to the bedside.

Funding: This research received no external funding.

Institutional Review Board Statement: Not applicable.

Informed Consent Statement: Not applicable.

Data Availability Statement: Not applicable.

Conflicts of Interest: The authors declare no conflict of interest.

\section{References}

1. Azadnajafabad, S.; Moghaddam, S.S.; Mohammadi, E.; Rezaei, N.; Ghasemi, E.; Fattahi, N.; Aminorroaya, A.; Azadnajafabad, R.; Aryannejad, A.; Rezaei, N.; et al. Global, regional, and national burden and quality of care index (QCI) of thyroid cancer: A systematic analysis of the Global Burden of Disease Study 1990-2017. Cancer Med. 2021, 10, 2496-2508. [CrossRef]

2. Miranda-Filho, A.; Lortet-Tieulent, J.; Bray, F.; Cao, B.; Franceschi, S.; Vaccarella, S.; Maso, L.D. Thyroid cancer incidence trends by histology in 25 countries: A population-based study. Lancet Diabetes Endocrinol. 2021, 9, 225-234. [CrossRef]

3. Sebastian, S.O.; Gonzalez, J.M.; Paricio, P.P.; Perez, J.S.; Flores, D.P.; Madrona, A.P.; Romero, P.R.; Tebar, F.J. Papillary thyroid carcinoma: Prognostic index for survival including the histological variety. Arch. Surg. 2000, 135, 272-277. [CrossRef]

4. Haugen, B.R.; Alexander, E.K.; Bible, K.C.; Doherty, G.M.; Mandel, S.J.; Nikiforov, Y.E.; Pacini, F.; Randolph, G.W.; Sawka, A.M.; Schlumberger, M.; et al. 2015 American Thyroid Association Management Guidelines for Adult Patients with Thyroid Nodules and Differentiated Thyroid Cancer: The American Thyroid Association Guidelines Task Force on Thyroid Nodules and Differentiated Thyroid Cancer. Thyroid 2016, 26, 1-133. [CrossRef]

5. Van Velsen, E.F.; Stegenga, M.T.; Van Kemenade, F.J.; Kam, B.L.; Van Ginhoven, T.M.; Visser, W.E.; Peeters, R.P. Evaluating the 2015 American Thyroid Association Risk Stratification System in High-Risk Papillary and Follicular Thyroid Cancer Patients. Thyroid 2019, 29, 1073-1079. [CrossRef]

6. Rousset, B.; Dupuy, C.; Miot, F.; Dumont, J. Chapter 2 Thyroid Hormone Synthesis and Secretion; MDText.com, Inc.: South Dartmouth, MA, USA, 2015.

7. Giovanella, L.; Suriano, S.; Ceriani, L.; Verburg, F.A. Undetectable Thyroglobulin in Patients with Differentiated Thyroid Carcinoma and Residual Radioiodine Uptake on a Postablation Whole-Body Scan. Clin. Nucl. Med. 2011, 36, 109-112. [CrossRef]

8. Robenshtok, E.; Grewal, R.K.; Fish, S.; Sabra, M.; Tuttle, R.M. A Low Postoperative Nonstimulated Serum Thyroglobulin Level Does Not Exclude the Presence of Radioactive Iodine Avid Metastatic Foci in Intermediate-Risk Differentiated Thyroid Cancer Patients. Thyroid 2013, 23, 436-442. [CrossRef]

9. De Rosário, P.W.S.; Guimarães, V.C.; Maia, F.F.R.; Fagundes, T.A.; Purisch, S.; Padrao, E.L.; Rezende, L.L.; Barroso, A.L. Thyroglobulin before Ablation and Correlation with Posttreatment Scanning. Laryngoscope 2005, 115, 264-267. [CrossRef]

10. Spencer, C.A. Clinical Utility of Thyroglobulin Antibody (TgAb) Measurements for Patients with Differentiated Thyroid Cancers (DTC). J. Clin. Endocrinol. Metab. 2011, 96, 3615-3627. [CrossRef]

11. Park, S.; Jeon, M.J.; Oh, H.-S.; Lee, Y.-M.; Sung, T.-Y.; Han, M.; Han, J.M.; Kim, T.Y.; Chung, K.-W.; Kim, W.B.; et al. Changes in Serum Thyroglobulin Levels After Lobectomy in Patients with Low-Risk Papillary Thyroid Cancer. Thyroid 2018, 28, $997-1003$. [CrossRef]

12. Wells, S.A.; Asa, S.; Dralle, H.; Elisei, R.; Evans, D.B.; Gagel, R.F.; Lee, N.Y.; Machens, A.; Moley, J.F.; Pacini, F.; et al. Revised American Thyroid Association Guidelines for the Management of Medullary Thyroid Carcinoma. Thyroid 2015, 25, 567-610. [CrossRef]

13. Toledo, S.P.; Lourenço, D.M.; Santos, M.A.; Tavares, M.R.; Toledo, R.A.; Correia-Deur, J.E.D.M. Hypercalcitoninemia is not pathognomonic of medullary thyroid carcinoma. Clinics 2009, 64, 699-706. [CrossRef]

14. Rondeau, G.; Fish, S.; Hann, L.E.; Fagin, J.A.; Tuttle, R.M. Ultrasonographically Detected Small Thyroid Bed Nodules Identified After Total Thyroidectomy for Differentiated Thyroid Cancer Seldom Show Clinically Significant Structural Progression. Thyroid 2011, 21, 845-853. [CrossRef]

15. Lin, E.C. Radiation Risk from Medical Imaging. Mayo Clin. Proc. 2010, 85, 1142-1146. [CrossRef] [PubMed]

16. Ricarte-Filho, J.C.; Ryder, M.; Chitale, D.; Rivera, M.; Heguy, A.; Ladanyi, M.; Janakiraman, M.; Solit, D.; Knauf, J.; Tuttle, R.M.; et al. Mutational Profile of Advanced Primary and Metastatic Radioactive Iodine-Refractory Thyroid Cancers Reveals Distinct Pathogenetic Roles for BRAF, PIK3CA, and AKT1. Cancer Res. 2009, 69, 4885-4893. [CrossRef] 
17. Brose, M.S.; Nutting, C.M.; Jarzab, B.; Elisei, R.; Siena, S.; Bastholt, L.; DE LA Fouchardiere, C.; Pacini, F.; Paschke, R.; Shong, Y.K.; et al. Sorafenib in radioactive iodine-refractory, locally advanced or metastatic differentiated thyroid cancer: A randomised, double-blind, phase 3 trial. Lancet 2014, 384, 319-328. [CrossRef]

18. Schlumberger, M.; Tahara, M.; Wirth, L.J.; Robinson, B.; Brose, M.S.; Elisei, R.; Habra, M.A.; Newbold, K.; Shah, M.H.; Hoff, A.O.; et al. Lenvatinib versus Placebo in Radioiodine-Refractory Thyroid Cancer. N. Engl. J. Med. 2015, 372, 621-630. [CrossRef]

19. Subbiah, V.; Kreitman, R.J.; Wainberg, Z.A.; Cho, J.Y.; Schellens, J.H.; Soria, J.C.; Wen, P.Y.; Zielinski, C.; Cabanillas, M.E.; Urbanowitz, G.; et al. Dabrafenib and Trametinib Treatment in Patients with Locally Advanced or Metastatic BRAF V600-Mutant Anaplastic Thyroid Cancer. J. Clin. Oncol. 2018, 36, 7-13. [CrossRef]

20. Wells, S.A., Jr.; Robinson, B.G.; Gagel, R.F.; Dralle, H.; Fagin, J.A.; Santoro, M.; Baudin, E.; Elisei, R.; Jarzab, B.; Vasselli, J.R.; et al. Vandetanib in Patients With Locally Advanced or Metastatic Medullary Thyroid Cancer: A Randomized, Double-Blind Phase III Trial. J. Clin. Oncol. 2012, 30, 134-141. [CrossRef] [PubMed]

21. Bettegowda, C.; Sausen, M.; Leary, R.J.; Kinde, I.; Wang, Y.; Agrawal, N.; Bartlett, B.R.; Wang, H.; Luber, B.; Alani, R.M.; et al. Detection of Circulating Tumor DNA in Early- and Late-Stage Human Malignancies. Sci. Transl. Med. 2014, 6, 224ra24. [CrossRef]

22. Mandel, P.; Metais, P. Nuclear Acids in Human Blood Plasma. Comptes Rendus Seances Soc. Biol. Ses Fil. 1948, 142, $241-243$.

23. Anker, P.; Mulcahy, H.; Chen, X.Q.; Stroun, M. Detection of Circulating Tumour DNA in the Blood (Plasma/Serum) of Cancer Patients. Cancer Metastasis Rev. 1999, 18, 65-73. [CrossRef] [PubMed]

24. Schwarzenbach, H.; Hoon, D.S.B.; Pantel, K. Cell-free nucleic acids as biomarkers in cancer patients. Nat. Rev. Cancer 2011, 11, 426-437. [CrossRef] [PubMed]

25. Teo, Y.V.; Capri, M.; Morsiani, C.; Pizza, G.; Faria, A.M.; Franceschi, C.; Neretti, N. Cell-free DNA as a biomarker of aging. Aging Cell 2019, 18, e12890. [CrossRef]

26. Volik, S.; Alcaide, M.; Morin, R.D.; Collins, C.C. Cell-free DNA (cfDNA): Clinical Significance and Utility in Cancer Shaped by Emerging Technologies. Mol. Cancer Res. 2016, 14, 898-908. [CrossRef]

27. O'Connell, G.C.; Petrone, A.B.; Tennant, C.S.; Lucke-Wold, N.; Kabbani, Y.; Tarabishy, A.R.; Chantler, P.D.; Barr, T.L. Circulating extracellular DNA levels are acutely elevated in ischaemic stroke and associated with innate immune system activation. Brain Inj. 2017, 31, 1369-1375. [CrossRef]

28. Lee, J.; Park, S.S.; Lee, Y.K.; Norton, J.A.; Jeffrey, S.S. Liquid biopsy in pancreatic ductal adenocarcinoma: Current status of circulating tumor cells and circulating tumorDNA. Mol. Oncol. 2019, 13, 1623-1650. [CrossRef]

29. Ried, K.; Eng, P.; Sali, A. Screening for Circulating Tumour Cells Allows Early Detection of Cancer and Monitoring of Treatment Effectiveness: An Observational Study. Asian Pac. J. Cancer Prev. 2017, 18, 2275-2285. [CrossRef] [PubMed]

30. Passiglia, F.; Rizzo, S.; Di Maio, M.; Galvano, A.; Badalamenti, G.; Listì, A.; Gulotta, L.; Castiglia, M.; Fulfaro, F.; Bazan, V.; et al. The diagnostic accuracy of circulating tumor DNA for the detection of EGFR-T790M mutation in NSCLC: A systematic review and meta-analysis. Sci. Rep. 2018, 8, 1-10. [CrossRef]

31. Singh, A.P.; Li, S.; Cheng, H. Circulating DNA in EGFR-mutated lung cancer. Ann. Transl. Med. 2017, 5, 379. [CrossRef]

32. Thierry, A.R.; Mouliere, F.; El Messaoudi, S.; Mollevi, C.; Crapez, E.; Rolet, F.; Gillet, B.; Gongora, C.; Dechelotte, P.; Robert, B.; et al. Clinical validation of the detection of KRAS and BRAF mutations from circulating tumor DNA. Nat. Med. 2014, 20, 430-435. [CrossRef]

33. Jones, R.P.; Pugh, S.A.; Graham, J.; Primrose, J.N.; Barriuso, J. Circulating tumour DNA as a biomarker in resectable and irresectable stage IV colorectal cancer; a systematic review and meta-analysis. Eur. J. Cancer 2021, 144, 368-381. [CrossRef]

34. Dawson, S.-J.; Tsui, D.W.; Murtaza, M.; Biggs, H.; Rueda, O.M.; Chin, S.-F.; Dunning, M.; Gale, D.; Forshew, T.; Mahler-Araujo, B.; et al. Analysis of Circulating Tumor DNA to Monitor Metastatic Breast Cancer. N. Engl. J. Med. 2013, 368, 1199-1209. [CrossRef] [PubMed]

35. Davis, A.A.; Jacob, S.; Gerratana, L.; Shah, A.N.; Wehbe, F.; Katam, N.; Zhang, Q.; Flaum, L.; Siziopikou, K.P.; Platanias, L.C.; et al. Landscape of circulating tumour DNA in metastatic breast cancer. EBioMedicine 2020, 58, 102914. [CrossRef]

36. Diaz, L.A., Jr.; Williams, R.T.; Wu, J.; Kinde, I.; Hecht, J.R.; Berlin, J.; Allen, B.; Bozic, I.; Reiter, J.G.; Nowak, M.A.; et al. The molecular evolution of acquired resistance to targeted EGFR blockade in colorectal cancers. Nature 2012, 486, 537-540. [CrossRef]

37. Russo, M.; Siravegna, G.; Blaszkowsky, L.S.; Corti, G.; Crisafulli, G.; Ahronian, L.G.; Mussolin, B.; Kwak, E.L.; Buscarino, M.; Lazzari, L.; et al. Tumor Heterogeneity and Lesion-Specific Response to Targeted Therapy in Colorectal Cancer. Cancer Discov. 2016, 6, 147-153. [CrossRef]

38. Misale, S.; Yaeger, R.; Hobor, S.; Scala, E.; Janakiraman, M.; Liska, D.; Valtorta, E.; Schiavo, R.; Buscarino, M.; Siravegna, G.; et al. Emergence of KRAS mutations and acquired resistance to anti-EGFR therapy in colorectal cancer. Nat. Cell Biol. 2012, 486, 532-536. [CrossRef]

39. Barbano, R.; Pasculli, B.; Coco, M.; Fontana, A.; Copetti, M.; Rendina, M.; Valori, V.M.; Graziano, P.; Maiello, E.; Fazio, V.M.; et al. Competitive allele-specific TaqMan PCR (Cast-PCR) is a sensitive, specific and fast method for BRAF V600 mutation detection in Melanoma patients. Sci. Rep. 2015, 5, 18592. [CrossRef] [PubMed]

40. Kinde, I.; Wu, J.; Papadopoulos, N.; Kinzler, K.W.; Vogelstein, B. Detection and quantification of rare mutations with massively parallel sequencing. Proc. Natl. Acad. Sci. USA 2011, 108, 9530-9535. [CrossRef] [PubMed]

41. Forshew, T.; Murtaza, M.; Parkinson, C.; Gale, D.; Tsui, D.W.Y.; Kaper, F.; Dawson, S.-J.; Piskorz, A.M.; Jimenez-Linan, M.; Bentley, D.; et al. Noninvasive Identification and Monitoring of Cancer Mutations by Targeted Deep Sequencing of Plasma DNA. Sci. Transl. Med. 2012, 4, 136ra68. [CrossRef] 
42. Newman, A.; Bratman, S.V.; To, J.; Wynne, J.F.; Eclov, N.C.W.; Modlin, L.A.; Liu, C.L.; Neal, J.W.; Wakelee, H.A.; Merritt, R.E.; et al. An ultrasensitive method for quantitating circulating tumor DNA with broad patient coverage. Nat. Med. 2014, 20, 548-554. [CrossRef] [PubMed]

43. Schmitt, M.W.; Kennedy, S.R.; Salk, J.J.; Fox, E.; Hiatt, J.B.; Loeb, L.A. Detection of ultra-rare mutations by next-generation sequencing. Proc. Natl. Acad. Sci. USA 2012, 109, 14508-14513. [CrossRef]

44. Paweletz, C.P.; Sacher, A.; Raymond, C.K.; Alden, R.S.; O'Connell, A.; Mach, S.L.; Kuang, Y.; Gandhi, L.; Kirschmeier, P.; English, J.M.; et al. Bias-Corrected Targeted Next-Generation Sequencing for Rapid, Multiplexed Detection of Actionable Alterations in Cell-Free DNA from Advanced Lung Cancer Patients. Clin. Cancer Res. 2016, 22, 915-922. [CrossRef]

45. Song, C.; Liu, Y.; Fontana, R.; Makrigiorgos, A.; Mamon, H.; Kulke, M.H.; Makrigiorgos, G.M. Elimination of unaltered DNA in mixed clinical samples via nuclease-assisted minor-allele enrichment. Nucleic Acids Res. 2016, 44, e146. [CrossRef]

46. Lee, S.H.; Yu, J.; Hwang, G.-H.; Kim, S.; Kim, H.S.; Ye, S.; Kim, K.; Park, J.; Park, D.Y.; Cho, Y.-K.; et al. CUT-PCR: CRISPRmediated, ultrasensitive detection of target DNA using PCR. Oncogene 2017, 36, 6823-6829. [CrossRef] [PubMed]

47. Ladas, I.; Yu, F.; Leong, K.W.; Fitarelli-Kiehl, M.; Song, C.; Ashtaputre, R.; Kulke, M.; Mamon, H.; Makrigiorgos, G.M. Enhanced detection of microsatellite instability using pre-PCR elimination of wild-type DNA homo-polymers in tissue and liquid biopsies. Nucleic Acids Res. 2018, 46, e74. [CrossRef]

48. Liu, Y.; Song, C.; Ladas, I.; Fitarelli-Kiehl, M.; Makrigiorgos, G.M. Methylation-sensitive enrichment of minor DNA alleles using a double-strand DNA-specific nuclease. Nucleic Acids Res. 2016, 45, e39. [CrossRef]

49. Salvianti, F.; Giuliani, C.; Petrone, L.; Mancini, I.; Vezzosi, V.; Pupilli, C.; Pinzani, P. Integrity and Quantity of Total Cell-Free DNA in the Diagnosis of Thyroid Cancer: Correlation with Cytological Classification. Int. J. Mol. Sci. 2017, 18, 1350. [CrossRef]

50. Tomczak, K.; Czerwińska, P.; Wiznerowicz, M. Review the Cancer Genome Atlas (TCGA): An immeasurable source of knowledge. Wspótczesna Onkol. 2015, 1A, 68-77. [CrossRef] [PubMed]

51. Campennì, A.; Ruggeri, R.M.; Giuffrè, G.; Siracusa, M.; Alibrandi, A.; Cardile, D.; La Torre, F.; Lanzafame, H.; Giacoppo, G.; Ieni, A.; et al. BRAFV600E mutation is associated with increased prevalence of contralateral lymph-node metastases in low and low-to-intermediate risk papillary thyroid cancer. Nucl. Med. Commun. 2021, 42, 611-618. [CrossRef]

52. Xing, M.; Westra, W.H.; Tufano, R.P.; Cohen, Y.; Rosenbaum, E.; Rhoden, K.J.; Carson, K.A.; Vasko, V.; Larin, O.; Tallini, G.; et al. BRAF Mutation Predicts a Poorer Clinical Prognosis for Papillary Thyroid Cancer. J. Clin. Endocrinol. Metab. 2005, 90, 6373-6379. [CrossRef]

53. Elisei, R.; Viola, D.; Torregrossa, L.; Giannini, R.; Romei, C.; Ugolini, C.; Molinaro, E.; Agate, L.; Biagini, A.; Lupi, C.; et al. The $B R A F^{\mathrm{V} 600 \mathrm{E}}$ Mutation Is an Independent, Poor Prognostic Factor for the Outcome of Patients with Low-Risk Intrathyroid Papillary Thyroid Carcinoma: Single-Institution Results from a Large Cohort Study. J. Clin. Endocrinol. Metab. 2012, 97, 4390-4398. [CrossRef]

54. Xing, M.; Alzahrani, A.S.; Carson, K.A.; Shong, Y.K.; Kim, T.Y.; Viola, D.; Elisei, R.; Bendlová, B.; Yip, L.; Mian, C.; et al. Association Between BRAF V600E Mutation and Recurrence of Papillary Thyroid Cancer. J. Clin. Oncol. 2015, 33, 42-50. [CrossRef]

55. Xing, M.; Alzahrani, A.S.; Carson, K.A.; Viola, D.; Elisei, R.; Bendlova, B.; Yip, L.; Mian, C.; Vianello, F.; Tuttle, R.M.; et al. Association Between BRAF V600E Mutation and Mortality in Patients with Papillary Thyroid Cancer. JAMA 2013, 309, $1493-1501$. [CrossRef]

56. Santoro, M.; Melillo, R.M.; Fusco, A. RET/PTC activation in papillary thyroid carcinoma: European Journal of Endocrinology Prize Lecture. Eur. J. Endocrinol. 2006, 155, 645-653. [CrossRef]

57. Santoro, M.; Moccia, M.; Federico, G.; Carlomagno, F. RET Gene Fusions in Malignancies of the Thyroid and Other Tissues. Genes 2020, 11, 424. [CrossRef]

58. Wells, S.A.; Pacini, F.; Robinson, B.G.; Santoro, M. Multiple Endocrine Neoplasia Type 2 and Familial Medullary Thyroid Carcinoma: An Update. J. Clin. Endocrinol. Metab. 2013, 98, 3149-3164. [CrossRef]

59. Condello, V.; Macerola, E.; Ugolini, C.; De Napoli, L.; Romei, C.; Materazzi, G.; Elisei, R.; Basolo, F. Analysis of circulating tumor DNA does not improve the clinical management of patients with locally advanced and metastatic papillary thyroid carcinoma. Head Neck 2018, 40, 1752-1758. [CrossRef]

60. Kwak, J.Y.; Jeong, J.J.; Kang, S.-W.; Park, S.; Choi, J.R.; Park, S.-J.; Kim, E.K.; Chung, W.Y. Study of peripheral BRAF ${ }^{\mathrm{V} 600 \mathrm{E}}$ mutation as a possible novel marker for papillary thyroid carcinomas. Head Neck 2012, 35, 1630-1633. [CrossRef]

61. Jensen, K.; Thakur, S.; Patel, A.; Mendonca-Torres, M.C.; Costello, J.; Gomes-Lima, C.J.; Walter, M.; Wartofsky, L.; Burman, K.D.; Bikas, A.; et al. Detection of BRAFV600E in Liquid Biopsy from Patients with Papillary Thyroid Cancer Is Associated with Tumor Aggressiveness and Response to Therapy. J. Clin. Med. 2020, 9, 2481. [CrossRef]

62. Kim, B.H.; Kim, I.J.; Lee, B.J.; Lee, J.C.; Kim, S.-J.; Kim, W.J.; Jeon, Y.K.; Kim, S.S.; Kim, Y.K.; Kim, I.S. Detection of Plasma BRAF $^{V 600 E}$ Mutation is Associated with Lung Metastasis in Papillary Thyroid Carcinomas. Yonsei Med. J. 2015, 56, 634-640. [CrossRef]

63. Almubarak, H.; Qassem, E.; Alghofaili, L.; Alzahrani, A.S.; Karakas, B. Non-invasive Molecular Detection of Minimal Residual Disease in Papillary Thyroid Cancer Patients. Front. Oncol. 2020, 9. [CrossRef]

64. Cote, G.J.; Evers, C.; Hu, M.I.; Grubbs, E.G.; Williams, M.D.; Hai, T.; Duose, D.Y.; Houston, M.R.; Bui, J.H.; Mehrotra, M.; et al. Prognostic Significance of Circulating RET M918T Mutated Tumor DNA in Patients with Advanced Medullary Thyroid Carcinoma. J. Clin. Endocrinol. Metab. 2017, 102, 3591-3599. [CrossRef] 
65. Allin, D.M.; Shaikh, R.; Carter, P.; Thway, K.; Sharabiani, M.T.A.; Gonzales-de-Castro, D. Circulating tumour DNA is a potential biomarker for disease progression and response to targeted therapy in advanced thyroid cancer. Eur. J. Cancer 2018, 103, 165-175. [CrossRef]

66. Sandulache, V.C.; Williams, M.D.; Lai, S.; Lu, C.; William, W.N.; Busaidy, N.L.; Cote, G.J.; Singh, R.R.; Luthra, R.; Cabanillas, M.E. Real-Time Genomic Characterization Utilizing Circulating Cell-Free DNA in Patients with Anaplastic Thyroid Carcinoma. Thyroid 2017, 27, 81-87. [CrossRef]

67. Qin, Y.; Wang, J.R.; Wang, Y.; Iyer, P.C.; Cote, G.J.; Busaidy, N.L.; Dadu, R.; Zafereo, M.; Williams, M.D.; Ferrarotto, R.; et al. Clinical Utility of Circulating Cell-Free DNA Mutations in Anaplastic Thyroid Carcinoma. Thyroid 2021. [CrossRef]

68. Suh, Y.; Kwon, M.; Noh, H.-M.; Lee, H.; Ra, Y.; Kim, N. Limited Clinical and Diagnostic Utility of Circulating Tumor DNA Detection in Patients with Early-Stage Well-Differentiated Thyroid Cancer: Comparison with Benign Thyroid Nodules and Healthy Individuals. Healthcare 2021, 9, 386. [CrossRef]

69. Pupilli, C.; Pinzani, P.; Salvianti, F.; Fibbi, B.; Rossi, M.; Petrone, L.; Perigli, G.; De Feo, M.L.; Vezzosi, V.; Pazzagli, M.; et al. CirculatingBRAFV600Ein the Diagnosis and Follow-Up of Differentiated Papillary Thyroid Carcinoma. J. Clin. Endocrinol. Metab. 2013, 98, 3359-3365. [CrossRef]

70. Konda, B.; Shah, M.H.; Wei, L.; Espinosa, A.V.; Busaidy, N.L.; Wirth, L.J.; Daniels, G.A.; De Souza, J.A.; Sexton, J.L.; Beshara, M.; et al. Evaluation of BRAF ${ }^{\mathrm{V} 600 \mathrm{E}}$ levels in cell free DNA (CFDNA) as a biomarker of response in BRAF V600E mutated radioactive iodine refractory (RAIR) differentiated thyroid cancer (DTC) treated with dabrafenib alone or in combination with trametinib. Thyroid 2017, 27 (Suppl. 1), A171-A172. [CrossRef]

71. Besse, B.; Subbiah, V.; Drilon, A.; Shah, M.; Wirth, L.; Bauer, T.; Velcheti, V.; Lakhani, N.; Boni, V.; Solomon, B.; et al. Detection and clearance of RET variants in plasma cell free DNA (cfDNA) from patients (pts) treated with LOXO-292. Ann. Oncol. 2018, 29, viii33. [CrossRef]

72. Busaidy, N.L.; Cabanillas, M.E.; Sherman, S.I.; Habra, M.; Dadu, R.; Hu, M.I.; Jimenez, C.; Waguespack, S.E.; Subbiah, V.; Ying, A.; et al. Emergence of V804M resistance gatekeeper mutation in sporadic medullary thyroid carcinoma patients treated with TKI tyrosine kinase inhibitors. Thyroid 2017, 27 (Suppl. 1), A168. [CrossRef]

73. Lupo, M.; Guttler, R.; Geck, Z.; Tonozzi, T.R.; Kammesheidt, A.; Braunstein, G.D. Is measurement of circulating tumor dna of diagnostic use in patients with thyroid nodules? Endocr. Pract. 2018, 24, 453-459. [CrossRef]

74. Cao, S.; Yu, S.; Yin, Y.; Su, L.; Hong, S.; Gong, Y.; Lv, W.; Li, Y.; Xiao, H. Genetic alterations in cfDNA of benign and malignant thyroid nodules based on amplicon-based next-generation sequencing. Ann. Transl. Med. 2020, 8, 1225. [CrossRef]

75. Landa, I.; Ibrahimpasic, T.; Boucai, L.; Sinha, R.; Knauf, J.A.; Shah, R.; Dogan, S.; Ricarte-Filho, J.C.; Krishnamoorthy, G.P.; Xu, B.; et al. Genomic and transcriptomic hallmarks of poorly differentiated and anaplastic thyroid cancers. J. Clin. Investig. 2016, 126, 1052-1066. [CrossRef]

76. Pozdeyev, N.; Gay, L.M.; Sokol, E.S.; Hartmaier, R.; Deaver, K.E.; Davis, S.; French, J.D.; Borre, P.V.; LaBarbera, D.V.; Tan, A.C.; et al. Genetic Analysis of 779 Advanced Differentiated and Anaplastic Thyroid Cancers. Clin. Cancer Res. 2018, 24, 3059-3068. [CrossRef]

77. Cheng, L.; Jin, Y.; Liu, M.; Ruan, M.; Chen, L. HER inhibitor promotes BRAF/MEK inhibitor-induced redifferentiation in papillary thyroid cancer harboring BRAFV600E. Oncotarget 2017, 8, 19843-19854. [CrossRef]

78. Gild, M.L.; Topliss, D.; Learoyd, D.; Parnis, F.; Tie, J.; Hughes, B.; Walsh, J.; McLeod, D.; Clifton-Bligh, R.J.; Robinson, B.G. Clinical guidance for radioiodine refractory differentiated thyroid cancer. Clin. Endocrinol. 2017, 88, 529-537. [CrossRef]

79. Friedman, R.; Farh, K.K.-H.; Burge, C.B.; Bartel, D.P. Most mammalian mRNAs are conserved targets of microRNAs. Genome Res. 2008, 19, 92-105. [CrossRef]

80. Yao, R.; Wang, Y.; Chen, L.-L. Cellular functions of long noncoding RNAs. Nat. Cell Biol. 2019, 21, 542-551. [CrossRef]

81. Chou, C.-K.; Chen, R.-F.; Chou, F.-F.; Chang, H.-W.; Chen, Y.-J.; Lee, Y.-F.; Yang, K.D.; Cheng, J.-T.; Huang, C.-C.; Liu, R.-T. miR-146b is Highly Expressed in Adult Papillary Thyroid Carcinomas with High Risk Features Including Extrathyroidal Invasion and the BRAFV600E Mutation. Thyroid 2010, 20, 489-494. [CrossRef] [PubMed]

82. Peng, Y.; Li, C.; Luo, D.-C.; Ding, J.-W.; Zhang, W.; Pan, G. Expression Profile and Clinical Significance of MicroRNAs in Papillary Thyroid Carcinoma. Molecules 2014, 19, 11586-11599. [CrossRef]

83. Acibucu, F.; Dökmetaş, H.S.; Tutar, Y.; Elagoz, S.; Kilicli, F. Correlations between the Expression Levels of Micro-RNA146b, 221, 222 and p27Kip1 protein mRNA and the Clinicopathologic Parameters in Papillary Thyroid Cancers. Exp. Clin. Endocrinol. Diabetes 2014, 122, 137-143. [CrossRef]

84. Guo, Z.; Hardin, H.; Montemayor-Garcia, C.; Asioli, S.; Righi, A.; Maletta, F.; Sapino, A.; Lloyd, R.V. In Situ Hybridization Analysis of miR-146b-5p and miR-21 in Thyroid Nodules: Diagnostic Implications. Endocr. Pathol. 2015, 26, 157-163. [CrossRef]

85. Sondermann, A.; Andreghetto, F.M.; Moulatlet, A.C.B.; Victor, E.D.S.; De Castro, M.G.; Nunes, F.D.; Brandão, L.G.; Severino, P. MiR-9 and miR-21 as prognostic biomarkers for recurrence in papillary thyroid cancer. Clin. Exp. Metastasis 2015, 32, 521-530. [CrossRef]

86. Dai, L.; Wang, Y.; Chen, L.; Zheng, J.; Li, J.; Wu, X. MiR-221, a potential prognostic biomarker for recurrence in papillary thyroid cancer. World J. Surg. Oncol. 2017, 15, 1-6. [CrossRef]

87. Mazzaferri, E.L.; Jhiang, S.M. Long-term impact of initial surgical and medical therapy on papillary and follicular thyroid cancer. Am. J. Med. 1994, 97, 418-428. [CrossRef] 
88. Mitchell, P.S.; Parkin, R.K.; Kroh, E.M.; Fritz, B.R.; Wyman, S.K.; Pogosova-Agadjanyan, E.L.; Peterson, A.; Noteboom, J.; O'Briant, K.C.; Allen, A.; et al. Circulating microRNAs as stable blood-based markers for cancer detection. Proc. Natl. Acad. Sci. USA 2008, 105, 10513-10518. [CrossRef]

89. Zhang, A.; Wang, C.; Lu, H.; Chen, X.; Ba, Y.; Zhang, C.; Zhang, C.-Y. Altered Serum MicroRNA Profile May Serve as an Auxiliary Tool for Discriminating Aggressive Thyroid Carcinoma from Nonaggressive Thyroid Cancer and Benign Thyroid Nodules. Dis. Markers 2019, 2019, 3717683. [CrossRef]

90. Li, M.; Song, Q.; Li, H.; Lou, Y.; Wang, L. Circulating miR-25-3p and miR-451a May Be Potential Biomarkers for the Diagnosis of Papillary Thyroid Carcinoma. PLoS ONE 2015, 10, e0132403. [CrossRef]

91. Graham, M.E.R.; Hart, R.D.; Douglas, S.E.; Makki, F.M.; Pinto, D.M.; Butler, A.L.; Bullock, M.; Rigby, M.H.; Trites, J.R.B.; Taylor, S.M.; et al. Serum microRNA profiling to distinguish papillary thyroid cancer from benign thyroid masses. J. Otolaryngol. Head Neck Surg. 2015, 44, 1-9. [CrossRef] [PubMed]

92. Rosignolo, F.; Sponziello, M.; Giacomelli, L.; Russo, D.; Pecce, V.; Biffoni, M.; Bellantone, R.; Lombardi, C.P.; Lamartina, L.; Grani, G.; et al. Identification of Thyroid-Associated Serum microRNA Profiles and Their Potential Use in Thyroid Cancer Follow-Up. J. Endocr. Soc. 2017, 1, 3-13. [CrossRef]

93. Yu, S.; Liu, Y.; Wang, J.; Guo, Z.; Zhang, Q.; Yu, F.; Zhang, Y.; Huang, K.; Li, Y.; Song, E.; et al. Circulating MicroRNA Profiles as Potential Biomarkers for Diagnosis of Papillary Thyroid Carcinoma. J. Clin. Endocrinol. Metab. 2012, 97, 2084-2092. [CrossRef]

94. Kondrotienè, A.; Daukša, A.; Pamedytytè, D.; Kazokaite, M.; Žvirblienè, A.; Daukšienè, D.; Simanavičienė, V.; Klimaite, R.; Golubickaitè, I.; Stakaitis, R.; et al. Plasma-Derived miRNA-222 as a Candidate Marker for Papillary Thyroid Cancer. Int. J. Mol. Sci. 2020, 21, 6445. [CrossRef] [PubMed]

95. Yoruker, E.E.; Terzioglu, D.; Teksoz, S.; Uslu, F.E.; Gezer, U.; Dalay, N. MicroRNA Expression Profiles in Papillary Thyroid Carcinoma, Benign Thyroid Nodules and Healthy Controls. J. Cancer 2016, 7, 803-809. [CrossRef] [PubMed]

96. Zou, X.; Gao, F.; Wang, Z.-Y.; Zhang, H.; Liu, Q.-X.; Jiang, L.; Zhou, X.; Zhu, W. A three-microRNA panel in serum as novel biomarker for papillary thyroid carcinoma diagnosis. Chin. Med. J. 2020, 133, 2543-2551. [CrossRef]

97. Ferracin, M.; Lupini, L.; Salamon, I.; Saccenti, E.; Zanzi, M.V.; Rocchi, A.; Da Ros, L.; Zagatti, B.; Musa, G.; Bassi, C.; et al. Absolute quantification of cell-free microRNAs in cancer patients. Oncotarget 2015, 6, 14545-14555. [CrossRef]

98. Lee, Y.S.; Lim, Y.S.; Lee, J.-C.; Wang, S.-G.; Park, H.-Y.; Kim, S.Y.; Lee, B.-J. Differential expression levels of plasma-derived miR-146b and miR-155 in papillary thyroid cancer. Oral Oncol. 2015, 51, 77-83. [CrossRef]

99. Grawenda, A.M.; O'Neill, E. Clinical utility of RASSF1A methylation in human malignancies. Br. J. Cancer 2015, $113,372-381$. [CrossRef]

100. Liu, M.; Oxnard, G.; Klein, E.; Swanton, C.; Seiden, M.; Smith, D.; Richards, D.; Yeatman, T.J.; Cohn, A.L.; Lapham, R.; et al. Sensitive and specific multi-cancer detection and localization using methylation signatures in cell-free DNA. Ann. Oncol. 2020, 31, 745-759. [CrossRef]

101. Ihara, M.; Ashizawa, K.; Shichijo, K.; Kudo, T. Expression of the DNA-dependent protein kinase catalytic subunit is associated with the radiosensitivity of human thyroid cancer cell lines. J. Radiat. Res. 2019, 60, 171-177. [CrossRef] [PubMed]

102. Hu, S.; Ewertz, M.; Tufano, R.P.; Brait, M.; Carvalho, A.L.; Liu, D.; Tufaro, A.P.; Basaria, S.; Cooper, D.S.; Sidransky, D.; et al. Detection of Serum Deoxyribonucleic Acid Methylation Markers: A Novel Diagnostic Tool for Thyroid Cancer. J. Clin. Endocrinol. Metab. 2006, 91, 98-104. [CrossRef]

103. Zane, M.; Agostini, M.; Enzo, M.V.; Ide, E.C.; Del Bianco, P.; Torresan, F.; Boschin, I.M.; Pennelli, G.; Saccani, A.; Rubello, D.; et al. Circulating cell-free DNA, SLC5A8 and SLC26A4 hypermethylation, BRAF ${ }^{\mathrm{V} 600 \mathrm{E}}$ : A non-invasive tool panel for early detection of thyroid cancer. Biomed. Pharmacother. 2013, 67, 723-730. [CrossRef] 